\title{
Evaluation of a MOOC developed from educational principles based on behavioral theory
}

Helder Lima Gusso, helder.gusso@ufsc.br

João Henrique Schuster, jhschuster.ufsc@gmail.com

Pedro Henrique Pacheco Kannenberg, pedrokannenberg@hotmail.com

Aline Battisti Archer, alinearcherr@gmail.com

Caio Medeiros de Oliveira, caio.med.ol@gmail.com

Maria Laura Silveira dos Santos, marialaurasilveirads@gmail.com

Valentina Pittol Nercolini, valentina.nercolini@gmail.com

Department of Psychology, Federal University of Santa Catarina (Brazil)

Campus Universitário - Trindade

CEP 88.040-970 - Florianópolis

Santa Catarina - Brazil 


\begin{abstract}
This study's objective was to evaluate a MOOC constructed from educational principles based on behavioral theory. The evaluation included the analysis of the performance, retention, and perception of the students. This MOOC consisted of an initial test, three teaching units, a final test and an assessment of the students' perception. The mean grade in the initial test was $6.34(s d=1.20)$, and in the last attempt of the final test it was $8.75(s d=0.51)$. The difference between these values was statistically significant and the effect size was considered very large. The retention rate was $44 \%$, and $75 \%$ of students rated the overall experience as "Very Good". The evaluated MOOC was effective in teaching its learning objectives and student retention was much higher than the average reported in other studies. These results indicate the relevance of the educational principles used in the elaboration of the MOOC.
\end{abstract}

Keywords: Massive Open Online Course (MOOC); Online learning; Teaching strategies; Higher Education. 


\section{Introduction}

Comprehending an online learning platform requires clarity about some of the concepts and principles involved in its operation. The concept of online learning refers to the appropriation of digital technologies by professionals of a broader field, called distance learning (Kaplan \& Haelein, 2016; Moore et al., 2011). Online Learning can be defined as "learning that takes place partially or entirely over the Internet" (Means et al., 2009, p.9). It has become popular both as a complement and as a flexible and accessible alternative to face-to-face teaching (Means et al., 2009). In 2020, as a result of the interruption of face-to-face teaching activities due to the COVID-19 pandemic, the relevance of research on this topic was highlighted (Martin et al., 2020).

One of the specific fields of study and intervention in online learning is Massive Open Online Courses (MOOCs) (Martin et al., 2020). To comprehend this phenomenon, according to Saalman (2014), it is necessary to understand the meaning of the words (1) massive, which indicates that courses are designed to enable large numbers of students on the platform without direct intervention from tutors or teachers - and (2) open, which, in general, denotes that the student is free to join and leave the course at any time (Baturay, 2015). The development of MOOCs can occur based on different educational foundations and principles (Baturay, 2015; Martin et al., 2020).

The MOOCs are offered on online learning platforms, which are systems developed to promote teaching and learning, typically providing tools for content exposure, communication, evaluation, forums, student group management, and monitoring, among others (Weller, 2007; Martin-Blas \& Serrano-Fernández, 2009). Martin-Blas and Serrano-Fernández (2009) highlight that these platforms can be found in the literature with different terms, such as Virtual Learning Environment (VLE) and Learning Management Systems (LMS). Online learning platforms can be commercial or open-source software, with Moodle being one of the most used open-source programs (Martin-Blas \& Serrano-Fernández, 2009).

Moodle, originally an acronym for Modular Object-Oriented Dynamic Learning Environment, is a free system that enables the creation of motivating and flexible online learning experiences, organized into independent modules (Rice, 2006; Kumar et al., 2011). It is a good alternative base system for managing MOOCs, as it offers tools that make it possible to configure courses in a Massive and Open mode (Saalman, 2014). In courses developed in Moodle, the teaching material consists of pages that can contain text, graphics, audio, videos, exercises, and games, among other things (Rice, 2006). This material can be divided into static material, which the student only views, and interactive material such as answering questions, uploading files and participating in chats, forums or peer review activities (Rice, 2006). The presentation of specific feedback by item or questions regarding the student's performance in the exercises is among the interaction possibilities offered by Moodle.

Despite the tools it offers, the mere adoption of an LMS is not enough to guarantee good teaching and learning conditions. To develop relevant learning that enables the student to deal with problem-situations of life in society (Botomé, 1981; Gusso et al., 2020; Kubo \& Botomé, 2001; Cortegoso \& Coser, 2011), teachers or instructional designers need to have clarity regarding the educational principles that underlie the decisions in the design of the course. These principles can be understood as guidelines to be taken into account when the teacher designs the online course, which, in turn, produce implications for the process of designing the course. 


\subsection{Principles and theories that underlie MOOCs}

Platforms offering MOOCs can be guided by different educational principles (Baturay, 2015; Hidalgo et al., 2020; Rice, 2006). The decision on which principles to use in the design of the courses has been influenced by evidence-based practices in education (American Educational Research Association, 2006; Diery et al., 2020). There is an effort by the scientific community to reduce the gaps between research and practice and to disseminate empirically supported practices at all levels and modalities of teaching (Cook et al., 2012). An example of work with great impact in this direction was the publication of the book Visible Learning, in which Hattie (2009) synthesizes 50,000 systematic reviews and 800 meta-analyses already published on interventions in education. Hattie (2009) presents a ranking of the most effective interventions, based on the effect size reported in the systematic reviews. Among some of the indications related to teaching that can be adopted in the context of MOOCs with strong evidence of effectiveness are: providing formative evaluation, feedback, problem-solving teaching, direct instruction, and mastery learning.

In a specific study in the field of MOOCs, Kasch et al. (2021) present a synthesis of best educational practices that enable the scalability of the courses. Based on the results of the study, the authors present seven recommendations for the development of MOOCs:

(1) constructive alignment regarding learning goals and activities; (2) automated (personalized) formative feedback, elaborating on correct and incorrect answers; (3) supported and trained peer-feedback activities; (4) authentic practices through simulations and games; (5) content and process hints; (6) structured online interaction and communication; and (7) use of external materials and content experts (p.10).

The use of empirically supported principles or practices increases the chances that the courses offered are of good quality, raising the level of learning, increasing student adherence to the teaching activities or improving the overall student experience in the courses.

Although different educational principles can be included in isolation in the development of online courses, these principles are developed in their own theoretical systems, formulated based on specific assumptions. There is a risk that the adoption of practices developed from different theories will lead to conceptual and methodological confusion. Thus, the adoption of empirically supported practices must take into account consistency with the theoretical assumptions that guide the development of the courses.

A theoretical model in the field of instructional design that has guided the development of several MOOCs is that of Merril (2002; 2013). In the author's proposition, decisions about the characteristics and principles to be used in the courses should be guided by five general assumptions, related to the need for (1) teaching to develop relevant learning to deal with real-world problems (problem-centered); (2) the student's existing repertoire of knowledge and skills being used as a basis for new learning (activation); (3) what the student is expected to present being clearly presented to them (demonstration); (4) the development of the learning involving active student participation (application); (5) the new learning being integrated into the student's life (integration). 


\subsubsection{Educational principles derived from behavioral theory}

Just as Merril $(2002 ; 2013)$ proposed a theoretical model in the context of instructional design, in the field of Psychology there are widely known theories to support actions in education, such as behaviorism, cognitivism and constructivism (Lowyck, 2014). The behaviorist theory, in particular, has often been presented in recent publications on online education in a rather caricatured way (e.g., Capacho, 2018; Siemens, 2014), making references to characteristics of an initial version of behaviorism, not to contemporary neo-behaviorists concepts. Contemporary behaviorist concepts are not compatible with ideas of a human being as a blank slate, neither do they ignore events private to the individual, focus only on stimulus-response relationships, nor understand the student as a passive being, as indicated in some publications (e.g., Radianti et al., 2020; Siemens, 2014). Sufficient responses to demonstrate the inadequacy of this characterization have already been widely published (e.g., Baum, 2017; Carrara, 2005; Chiesa, 1994; Skinner, 1974). A contemporary behaviorist conception has as its object of study the complex interactions between individuals and the social environment in which they live, and adopts different methods for the production of knowledge and a pragmatist position with a philosophical orientation in the construction of its theory (Botomé, 2013; Tourinho, 2003).

Specifically in the field of education, two of the oldest and most well-known contributions of behaviorism theory are programmed instruction (Skinner, 1986) and the Personalized System of Instruction or Keller Plan (Keller \& Sherman, 1974). From the 1980s onwards, one of the creators of the Keller Plan (Akera, 2017), professor Carolina Martuscelli Bori, developed a behaviorist contribution applied to education as a critique of what behaviorists had been developing as programmed teaching (Matos, 1998; Nale, 1998). This contribution has been designated as "Programming of Teaching", an expression that refers to the teacher's decision-making process to plan, carry out and evaluate the teaching-learning processes based on concepts, principles and procedures derived from a contemporary understanding of behavioral theory (Kienen et al, 2013; Kubo \& Botomé, 2001).

Programming of Teaching is a neo-behaviorist concept, which presents the following general principles to promote learning: (1) emphasis on what the student should be able to do in the real world; (2) consideration of the estimated repertoire of the course's target audience; (3) active student participation; (4) complete and gradual mastery of knowledge and skills by the student; (5) use of informative and immediate feedback on the student's performance; (6) emphasis on the use of positive reinforcement; (7) respect for the individual learning pace; and (8) continuous course improvement based on empirical data. Although many of these principles are not exclusive contributions from the Programming of Teaching, they are integrated into it and this integration is guaranteed by the theoretical support and coherence throughout its development and empirical validation (e.g., Botomé, 1981; De Luca, 2013; Kawasaki, 2013; Vettorazzi et al., 2005), which makes it even more relevant to be used in course development processes. 


\subsection{Operanda: A MOOC platform developed from the Programming of Teaching}

The first system for massive and open online teaching constructed based on Programming of Teaching is Operanda. This online system was constructed using the Moodle LMS and was developed by a Brazilian public university. The aforementioned system offers online courses of complementary scientific training relevant to the performance of higher education professionals, publicly and free of charge, in Portuguese. In Table 1, there is a description of the educational principles assumed in the Operanda online teaching system and their implications for teachers.

Table 1. Description of the educational principles used for the elaboration of courses in the Operanda online teaching system and their implications for the design of courses.

\begin{tabular}{ll}
\hline $\begin{array}{c}\text { Educational } \\
\text { Principles }\end{array}$ & \multicolumn{1}{c}{ Description } \\
\hline $\begin{array}{l}\text { Emphasis on } \\
\text { what the student } \\
\text { should be able } \\
\text { to do in the real }\end{array}$ & $\begin{array}{l}\text { The function of } \\
\text { the teaching } \\
\text { morld }\end{array}$ \\
& $\begin{array}{l}\text { make the student } \\
\text { able to deal with } \\
\text { the problem- } \\
\text { situations of life } \\
\text { in society, after } \\
\text { participating in } \\
\text { the course. }\end{array}$ \\
\end{tabular}

\section{Main implications for the design of courses $\quad$ References}

(a) Proposition of relevant learning objectives that Main references: express the knowledge and skills that the student must Botomé, 1981; present in their professional performance or in the Cortegoso \& exercise of citizenship;

Coser, 2011; Kubo

(b) Elaboration of teaching activities analogous or \& Botomé, 2001. equivalent to the situations the student will deal with after the course;

Related

(c) Assessment, in the context of teaching, whether the references: student is able to present the expected knowledge and Archer, 2020; skills;

Anderson, 2005;

(d) Assessment, after the course, (1) whether the student Bloom, 1956; is able to present the expected knowledge and skills Merril 2002, 2013; and (2) whether these solve the problem-situations for Pophan \& Baker, which the course was designed.

1976.

Consideration of the estimated repertoire of the course's target audience

\begin{abstract}
The course must start from the estimated previous knowledge and skills of the target audience of the course, making explicit the minimum requirements to make the course possible.
\end{abstract}

(a) Decision regarding the target audience of the course;

(b) Identification of what the student needs to be able to do to start the course;

(c) Decomposition of the course's learning objectives to the skills and knowledge already presented by the student;

(d) Production of course content in order to ensure that all students are able to start it;

(e) Content adequacy, based on the students' initial performance in the course.
Main references:

Cortegoso \&

Coser, 2011;

Cortegoso, 2011a.

Related

references:

Freire, 1996;

Merril, 2002;

2013.

$\begin{array}{ll}\text { Active student } & \text { In the course, the } \\ \text { participation } & \text { student must } \\ & \text { present in a } \\ & \text { participative } \\ & \text { way the } \\ & \text { knowledge and }\end{array}$

(a) Design of exercises in which the student must present, in a situation analogous or equivalent to the real world, the skills and knowledge that the course aims to develop;

(b) Design of one or more exercises after all new content has been presented to the student in the teaching
Main reference:

Keller \& Sherman, 1974; Svenningsen et al, 2018.

Related 
skills that they

will present in

the real world. material.

references:

Felder \& Brent,

2016; Pophan \&

Baker, 1976;

Merril, 2002,

2013.

$\begin{array}{ll}\begin{array}{l}\text { Complete and } \\ \text { gradual mastery }\end{array} & \text { In a course, the } \\ \text { student must } \\ \text { of knowledge } & \text { learn the } \\ \text { and skills by the } & \text { knowledge and } \\ \text { student } & \text { skills } \\ & \text { proficiently, } \\ \text { progressively } \\ \text { (gradual } & \text { (from the } \\ \text { mastery of } & \text { simplest to the } \\ \text { knowledge and } & \text { most complex) } \\ \text { skills) } & \text { and in small } \\ & \text { steps. }\end{array}$

Complete and gradual mastery

of knowledge and skills by the

\section{Use of} informative and immediate feedback on the student's performance
The feedback on exercises must indicate as accurately and as immediately as possible information about the student's successes and errors. (a) Sequencing of learning objectives from the simplest to the most complex;

(b) Gradual presentation of teaching material (i.e., content and exercises) to the student;

(c) Decision on the quantity and size of teaching units that make up a course;

(d) Decision on the amount of content that is presented to the student per screen;

(e) Definition of proficiency criteria in each course unit;

(f) Presentation of feedback on the exercises to the student;

(g) Creation of opportunities for the student to redo the exercises, until reaching the established proficiency criteria.
Main reference:

Keller \& Sherman, 1974; Svenningsen et al., 2018.

\section{Related}

references:

Bloom, 1968;

Cortegoso \&

Coser, 2011; Fox, 2004; Kulik et al.,

1990; Mccourt,

2019. (a) Preparation of feedback for each alternative answer to the exercises;

(b) Preparation of feedback that enables the student to identify the reason why the answer to the exercise was wrong or right;

(c) Preparation of feedback that allows the student to integrate what is being asked and the content presented prior to the exercise;

(d) Configuration of exercises in the system so that feedback is presented to the student as immediately as possible after their response.
Main reference:

Botomé \& Rizzon, 1997; Svenningsen et al., 2018.

Related

references:

Hattie \&

Timperley, 2007; Lopes et al., 2018; Sancho-Vinuesa et al., 2013.

Main references:

Sidman, 1989;

Skinner, 1968. the use of

positive

reinforcement
The exercises, feedback, and user experience in the course are planned to be as gratifying as possible. (a) Development of teaching activities that are perceived as relevant by the student for their professional performance or in their exercise of citizenship.

(b) Development of feedback that values the correct responses of students in the activities.

(c) Use of clear language for the students.

(d) Course structuring that is visually friendly, pleasant, attractive, and understandable.

(e) Exhibition of information on each course screen in a manner that guides the students on what they should do next.

(f) Avoidance of punishment so that students do not feel unmotivated or discouraged to continue the course.

\begin{tabular}{|c|c|c|c|}
\hline $\begin{array}{l}\text { Respect for the } \\
\text { individual pace } \\
\text { of learning }\end{array}$ & $\begin{array}{l}\text { The course must (a) } \\
\text { be designed to } \\
\text { ensure that the } \\
\text { student can run }\end{array}$ & $\begin{array}{l}\text { Availability of the course on the platform for an } \\
\text { unlimited time: the student can start whenever they } \\
\text { want, pause whenever they want and take as much time } \\
\text { as necessary to complete it; }\end{array}$ & $\begin{array}{l}\text { Main references: } \\
\text { Keller \& Sherman, } \\
\text { 1974; } \\
\text { Fox, 2004; }\end{array}$ \\
\hline
\end{tabular}




\section{it with the \\ minimum of \\ time restrictions \\ that control the \\ development of \\ their learning.}

(b) Provision of teaching material for review, as needed by the student.

The course must be continually refined based on data about the course itself.
Continuous

course improvement based on empirical data
Svenningsen et al., 2018.

Related

references:

Días et al, 2015.
(a) Identification of relevant variables to be monitored to enable continuous improvement of the course (e.g., performance, user satisfaction and experience, clarity and reliability of information);
(b) Development of instruments and procedures that make it possible to measure the variables defined as relevant (e.g., tests and questionnaires in the course, conducting a pilot group, development of an expert evaluation);
(c) Data collection and analysis;
(d) Decision on necessary referrals to improve the course based on the data;
(e) Intervention on the course, based on decisions for its continuous improvement.
Main reference:
Botomé, 1981;
Archer, 2020.
Related
references:
Kirkpatrick \&
Kirkpatrick
(2006).

\begin{abstract}
Note: The references indicated in the last column of the table present similarities to the principles we propose but are not necessarily based on the same theoretical system. Therefore, the "main references" are the references that directly support the construction of the Operanda online teaching system and are from the same theoretical system (i.e., contemporary behaviorist conception). The "related references" are references that are not based on the contemporary behaviorist conception but are still related to the described educational principles and indirectly support the construction of Operanda.
\end{abstract}

\title{
1.3. Evaluation of MOOCs
}

One of the problems with the potential for large-scale action of MOOCs is the lack of evaluation in relation to the effectiveness of the teaching promoted by the platforms (Atiaja \& Guerrero-Proenza, 2016). Few studies have been produced with the aim of evaluating the practices carried out within MOOC environments. This fact undermines the credibility of courses on platforms that end up not having evidence that solidly substantiates their existence as a teaching method (Tahiri et al., 2015; Alturkistani et al., 2020).

From this perspective, Alturkistani et al. (2020) conducted a systematic review with the aim of identifying the main methods used to assess MOOCs. The authors grouped the measures used in the studies into categories, of which four can be highlighted as they contain the greatest number of items: learning outcomes, learner participation or engagement, learner experience and learner expectation. A preference for quantitative methods for data analysis, such as inferential and descriptive statistics, was also evidenced, as well as highlighting the use of qualitative methods, through thematic analysis.

Discussing the importance of clearer measures for comparing educational methods, Hattie $(2009$; 2017) mentioned the effect size (Cohen's $d$ ), a measure of difference in standardized means, as a relevant alternative to be considered for the assessment of the teaching quality. The effect size expresses the magnitude of the difference between the measures, being useful to compare results of different measures, either in intra-group or between-group designs (Espírito-Santo \& Daniel, 2015). The classic interpretation of effect size values indicates the 
range between $0.50-0.79$ as medium values, $0.80-1.29$ as large, and above 1.30 as very large (Rosenthal, 1996). Hattie $(2009 ; 2017)$ highlighted that educational interventions with an effect size (Cohen's $d$ ) greater than 0.40 should be considered by those planning education. It is also interesting to highlight the fact that scientific associations such as the American Educational Research Association (AERA) and the American Psychological Association (APA) have encouraged the use of effect sizes in psychology and education papers as a measure to facilitate the dissemination and comparison of results of studies (AERA, 2006; APA, 2010).

\subsection{Objectives of the Work}

The aim of this study was to evaluate a MOOC offered on the Operanda platform, constructed based on the Programming of Teaching theory. The evaluation included the analysis of the performance, retention, and perception of the students.

\section{Method}

\subsection{The Operanda Platform}

The Operanda platform uses the Moodle open-source learning management system (v.3.8). Its courses are made available publicly and free of charge and are prepared, updated and evaluated by teams formed by undergraduate students, graduate students and professors, considering the principles summarized in Table 1 .

In order to enable the development of the platform as a highly scalable and low-cost MOOC, courses are designed so that students do not rely on direct interaction with tutors, hence, courses do not have synchronous activities.

The courses offered on the platform consist of the following steps: I) initial test; II) teaching units; III) final test; and IV) satisfaction survey. The initial test consists of a series of exercises to verify the students' performance in relation to the learning objectives of the course before coming into contact with the teaching conditions. The inclusion of initial tests in the courses makes it possible to compare the performance of students before and after their interaction with the teaching units. To ensure that the test questions effectively evaluated the learning objectives, a few steps have been taken. Two experienced professors on the course subjects and on the learning evaluation field used the learning objectives list and the course contents to plan the exam. After that, the course authors evaluated the test validity and format. As an external evaluation, researchers, teachers, professionals, and students from related fields were invited to evaluate both the test and the teaching conditions. As a final procedure, the professors who designed the test refined the questions, considering all the feedback.

The teaching units are composed of teaching materials, that is, contents (texts, videos, tables, illustrations, etc.) and exercises. Each of the exercises that comprise the teaching units has informative and specific feedback for each of its response alternatives. Students must obtain a minimum performance of $90 \%$ in the exercises of the teaching units to complete them, being able to redo them as many times as necessary without penalty. Students can start a teaching unit, leave the platform, and pick up the corresponding teaching unit where they left off at any time as their progress is automatically saved by the system. 
The final test consists of exactly the same set of exercises that make up the initial test. To be approved, students must achieve a minimum performance of $80 \%$. They can do it as often as necessary, as long as they do it with a minimum interval of one hour between each attempt, with no penalty on their final grade. The feedback from the final test is provided after its completion and is restricted to indicating the grade range in which the performance achieved by the students fits.

The student perception survey consists of a satisfaction questionnaire (Kirkpatrick \& Kirkpatrick, 2006), presented to the students after passing the final test, which aims to assess aspects of the course such as perceived learning, quality of teaching conditions and overall user experience. It consists of 15 multiple-choice questions, which are arranged on a five-item Likert-type scale, and an optional open-ended question in which students can leave suggestions, criticisms or compliments. The responses to the open question of the satisfaction survey were not evaluated in this work. Upon completion of these four constituent steps of each course, students receive a certificate attesting to completion of the course at the proficiency level.

\subsection{The course evaluated}

The course evaluated is called "Introduction to the observation of behavior" and is the first course offered on the platform. The overall learning objective of the course is to enable its students "to characterize observation of behavior". This objective was composed of three other specific learning objectives: "to characterize the observation process", "to characterize the behavior phenomenon" and "to characterize the properties of the components of behavior", which were decomposed into other 38 specific learning objectives.

The course consisted of six stages that had to be covered in the following order: an initial test, three teaching units, a final test and a satisfaction survey. Teaching units 1, 2 and 3 varied in size and consisted of teaching materials and 3, 19 and 32 exercises, respectively. The initial and final tests consisted of the same set of 18 multiple-choice questions. Of these, 11 were about the concepts involved in the course and five about applications of these concepts in behavior observation. The tests were formulated in such a way as to enable the evaluation of the students' performance in relation to the main learning objectives of the course, and the maximum grade that could be obtained was 10 .

\subsection{Participants}

Participants were 277 students, who completed the course. The students lived in Brazil, had a mean age of 25 years $(s d=7.9)$ and $206(74.4 \%)$ of them identified themselves as female. A total of 170 students said they lived in the Southern region of the country $(61.4 \%), 48$ in the Northeastern region (17.3\%), 46 in the Southeast (16.6\%), 10 in the Central-West region (3.6\%), and one, in the Northern region $(0.4 \%)$, with two students not reporting this information. Regarding education, 178 students $(64.3 \%)$ reported that they were doing undergraduate courses. Most of the students reported that they were taking or had already taken a course in Psychology during their undergraduate course (248 students, 89.5\%), and 184 students $(66.4 \%)$ reported having previously taken courses in the online format. 
Concerning the reasons for participating in the course available on the platform, 83 (30.0\%) students reported that they did so as a qualification for their professional training, 69 (24.8\%) to improve their scientific training, $51(18.4 \%)$ to learn new skills, $42(15.2 \%)$ as a requirement for a subject they were taking, $16(5.8 \%)$ out of curiosity about the course, 13 $(4.7 \%)$ to complete additional hours at the university, and $3(1.1 \%)$ for other reasons.

\subsection{Procedures}

We disseminated the course to 40 university professors that teach subjects related to behavior observation in different institutions and regions of Brazil. We asked these professors to also share the course with their students. In addition, we advertised the course on Operanda's social networks.

Data collection took place with students that took the course between May 24 and June 21,2020 , the period in which the course was made available openly. At the end of this period, we examined the data related to the performance and satisfaction of the students that completed the course. We extracted the data from the platform's database and subsequently organized and analyzed them using the Microsoft Excel (v .365) and SPSS (v.24) programs.

As this was a study carried out with a database, in which the information is aggregated, without the possibility of individual identification, in accordance with current legislation, this research did not need to be registered in the ethics system for research with human subjects in the country in which it was carried out. Even so, the students were aware that their data would be used for platform and course evaluation purposes, and they agreed to this when registering to use the platform.

\subsection{Data analysis}

We analyzed the following variables: course duration and completion rate; student performance at each stage of the course; and student satisfaction. To analyze the performance of students in the course, we used an one-group pretest-posttest quasi-experimental design (Breakwell et al., 2006; Shaughnessy et al., 2012). We examined the assessment of student learning in the course from the effect size measure (Cohen's $d$ ) and the analysis of differences between the means in the initial and final tests (Student's $t$-test for paired samples). To calculate the effect size in matched samples, we used the mean standard deviation of both matched groups: $\left(M_{1}-M_{2}\right) /\left(\left(S D_{1}+S D_{2}\right) / 2\right)$ (see Espírito-Santo \& Daniel, 2015).

\section{Results and Discussion}

\subsection{Course Duration and Completion Rate}

The median for the time taken to complete the course was 13 hours and 04 minutes. Given the wide variation in time among the students $(s d=111 \mathrm{~h} 26 \mathrm{~min})$, the mean time spent (65h38min) became an uninformative measure. Figure 1 presents the distribution between the number of students that took the course and the period of time taken to complete it. This data reproduces the sum of the time elapsed between the beginning and the conclusion of the 
constituent steps of the course, being, therefore, possible to count the periods during which the students interrupted the activities and left them open in the browser to resume them later.

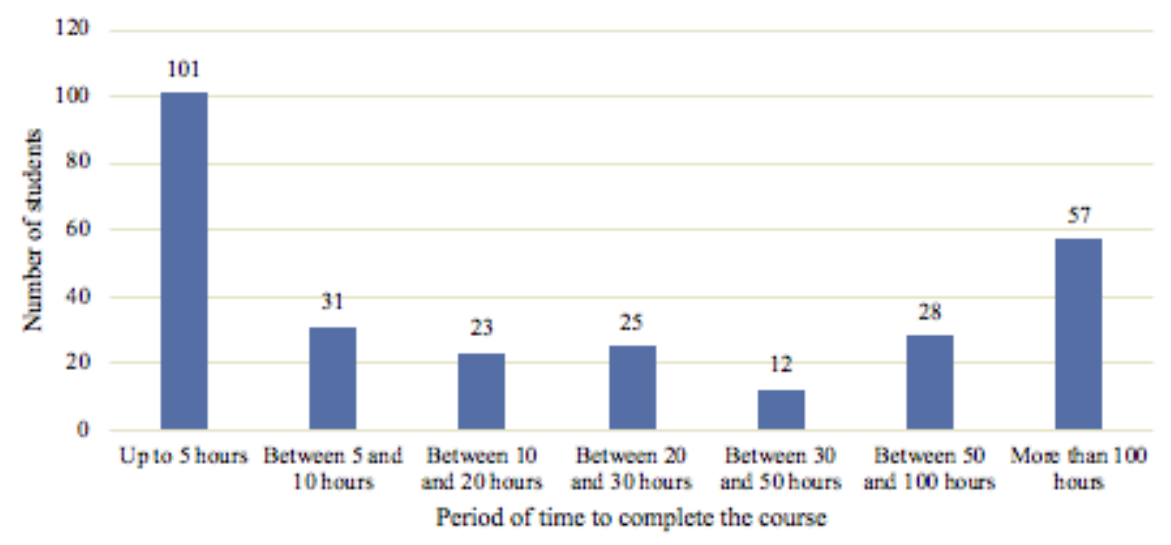

Figure 1. Distribution of the students that took the course according to the period of time taken to complete it.

Since the students could interrupt their activities in the course steps without prejudice, it is likely that most values above 30 hours indicate times of students that left the course step open in the browser while performing other activities. These extreme values, therefore, are not very informative for discussing the time needed to complete the course. Even disregarding these values, Figure 1 still shows a significant variation in the completion time required by each student. This variation represents the importance of the principle of respect for the individual pace of learning presented in Table 1.

Regarding the completion rate, 630 individuals enrolled in the course, of which 277 $(44.0 \%)$ completed it. This percentage is much higher than commonly seen in other studies on MOOCs, as retaining the students on courses is one of the biggest challenges in the area (Khalil \& Ebner, 2014; Dietz-Uhler et al., 2007; Paton et al., 2018). In a large study investigating courses available on some of the most popular MOOC platforms, Jordan (2014) identified a mean completion rate of just $6.5 \%$.

Some factors can collaborate to explain the high completion rate in the evaluated course. One of them is that data collection took place during the period of interruption of face-to-face teaching activities as a result of the Covid-19 pandemic. During this period, some of the Brazilian higher education institutions had online activities, while some suspended activities. It is also possible that the launch of a new platform by a highly recognized university in Brazil (listed among the top five in Brazil according to The World University Rankings, 2021), as well as the fact that $33.6 \%$ of the participants had never taken an online course, may have contributed. Another relevant factor is that one of the professors to whom the course was indicated, made it a mandatory activity for the students of her discipline. Although only 41 students stated that their main motivation for taking the course was "Requirement for discipline", 93 of those that concluded the course were students in this teacher's discipline. Excluding data from these students, the percentage of participants that completed the course is $34.26 \%$, maintaining a very high conclusion rate compared to the average reported in the literature. 
Another factor that probably contributed to the high retention of students was the principles used to construct the course. The proposition of relevant learning objectives to deal with the problem situations of life in society and the sequential programming of the course, requiring complete and gradual mastery of knowledge and skills, are factors that contribute to the higher completion rate (Muljana \& Luo, 2019). The demand for active student participation in a large number of exercises, accompanied by informative and immediate feedback on their performance in activities, is also a characteristic associated with high completion rates (Cowie \& Sakui, 2019; Gaytan, 2015).

\subsection{Student performance}

Table 2 presents the mean grades of the students' in the different stages of the course. The difference between the mean scores in the initial test and the first attempt at the final test was 1.49 points, while the difference between the initial test and the last attempt at the final test, in which the students fulfilled the proficiency criterion, was 2.51 . The grades in the exercises of the teaching units, in which there was specific and immediate informative feedback and the opportunity to redo the activities, were close to 10 .

Table 2. Mean performance of students in the stages of the course.

\begin{tabular}{|c|c|c|c|c|c|c|}
\hline & Initial test & Unit $1^{*}$ & Unit $2 *$ & Unit 3* & $\begin{array}{c}\text { First } \\
\text { attempt at } \\
\text { final test } * *\end{array}$ & $\begin{array}{c}\text { Last attempt } \\
\text { at final } \\
\text { test** }\end{array}$ \\
\hline $\begin{array}{c}\text { Mean grades } \\
\text { (standard deviation) }\end{array}$ & $\begin{array}{c}6.34 \\
(s d=1.20)\end{array}$ & $\begin{array}{c}9.96 \\
(s d=0.15)\end{array}$ & $\begin{array}{c}9.97 \\
(s d=0.14)\end{array}$ & $\begin{array}{c}9.92 \\
(s d=0.18)\end{array}$ & $\begin{array}{c}7.83 \\
(s d=1.23)\end{array}$ & $\begin{array}{c}8.75 \\
(s d=0.52)\end{array}$ \\
\hline
\end{tabular}

Note:

* The proficiency criterion in the units was 9.0.

** The final test proficiency criterion was 8.0.

When evaluated through the $t$-test for paired samples, the difference between the mean scores obtained in the initial test in relation to both the first attempt at the final test $(t(276)=$ $21.76, p=.000)$, and the last attempt $(t(276)=34.67, p=.000)$, were statistically significant and show that the differences cannot be attributed to standard error.

When comparing the results in the different measures through the effect size (Cohen's $d$ ), the difference between the initial test and the first attempt of the final test was 0.61 and 2.8 for the last attempt. Although there are no parameters for interpreting the effect size in specific studies in MOOCs, the extensive synthesis of systematic reviews carried out by Hattie (2009; 2017) on educational interventions can serve as a specific parameter for interpreting this result. The author proposes that values above 0.4 should be considered efficient educational interventions. In this sense, the effect size obtained in the first attempt of the final test indicates that the teaching conditions provided were effective in promoting learning. It is likely that the use of the principles used in the preparation of the MOOC described in Table 1 made this result possible.

When considering the very large effect size in the last attempt of the final test, it is likely that the opportunity to re-study the teaching units and retake the final test, and implications of 
the principle of requirement of complete mastery of knowledge and skills by the student, were the main determinant of this.

The students needed to take the final test, a mean of 2.4 times to reach the criteria for approval, and, as shown in Figure 2, 20 of these participants needed more than five attempts to achieve it. Two main factors could be highlighted for this high number of attempts: the lack of specific feedback regarding successes or errors in the final test and the participants' difficulty in interpreting a type of question used.

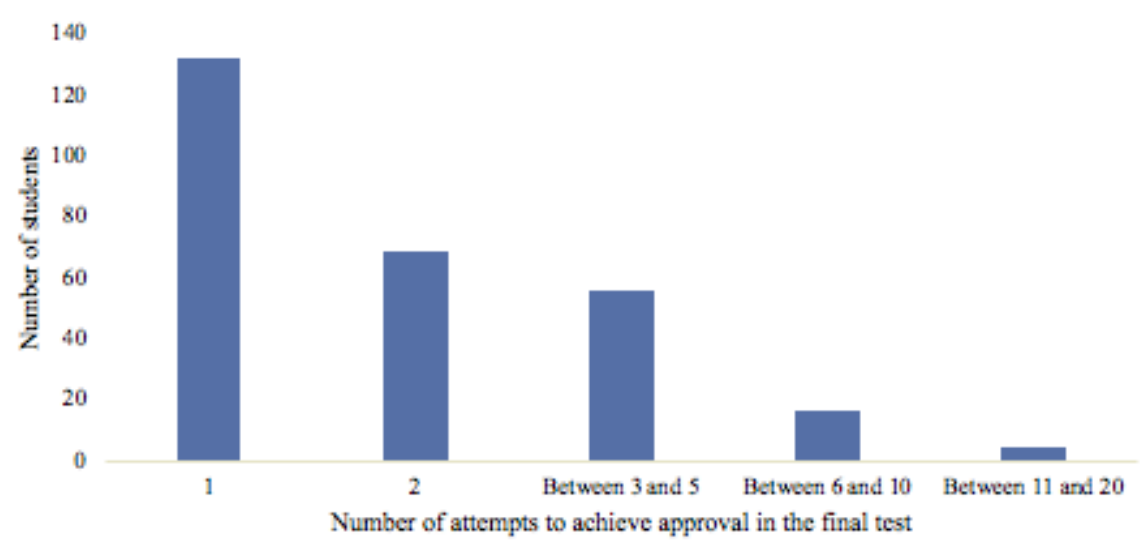

Figure 2. Distribution of the students that took the final test according to the number of attempts made to pass this test.

The final test was mostly used as a learning measure, with less emphasis on making it part of the learning process. Since it was composed of objective questions, there was no specific feedback regarding the success or errors, to avoid indicating the correct alternatives. The lack of accurate information about the errors may have made it difficult for students to understand what the learning gaps were and what course content needed to be studied again to improve their performance.

A second relevant aspect to explain the high mean number of attempts in the final test was the difficulty in interpreting the true or false model used in 10 of the test questions. These questions asked the student to indicate whether the definition presented was true or false. Many students struggled with these questions, considering not necessarily wrong but incomplete sentences as "true" definitions. This highlights a gap in the repertoire of students that participated in the course and an inadequacy of the platform's questionnaire in relation to its target audience. Although this problem was identified in the first responses to the final test, due to the data collection process it was not possible to make changes to these final test questions in order to avoid changes in the testing conditions.

It is possible to hypothesize that, if the two points presented above are resolved, the mean performance in the final test in the first attempt could be even greater, with fewer attempts necessary to achieve the proficiency criterion. 


\subsection{Students' perceptions}

Tables 3, 4 and 5 show the percentage distribution of responses given by students in relation to the 15 items of the satisfaction questionnaire that measured aspects of the course. The items are grouped according to the general categories they were part of: perceived learning, quality of teaching conditions, and overall user experience. As can be seen in these tables, all of the items were evaluated positively. Regarding the perceived learning, the students, in general, stated that they felt capable of comprehending what observation, behavior and behavior properties are. These data confirm the course's ability to contribute to the development of the learning expected and this perception probably affects students' interest in taking other courses on the platform, as indicated by most of them (Table 3).

Table 3. Percentage distribution of answers given by the students in relation to the learning perception category.

$\begin{array}{cccccc}\text { Learning perception } & \begin{array}{c}\text { Completely } \\ \text { disagree }\end{array} & \begin{array}{c}\text { Partially } \\ \text { disagree }\end{array} & \begin{array}{c}\text { Do not } \\ \text { agree or } \\ \text { disagree }\end{array} & \begin{array}{c}\text { Partially } \\ \text { agree }\end{array} & \begin{array}{c}\text { Completely } \\ \text { agree }\end{array} \\ \text { Items } & & \end{array}$

\begin{tabular}{lccccc}
\hline $\begin{array}{l}\text { After finishing this course, I feel able to } \\
\text { understand what observation is. }\end{array}$ & $0.00 \%$ & $0.72 \%$ & $1.44 \%$ & $19.86 \%$ & $\mathbf{7 7 . 9 8 \%}$ \\
$\begin{array}{l}\text { After finishing this course, I feel able to } \\
\text { understand what behavior is. }\end{array}$ & $0.00 \%$ & $0.00 \%$ & $0.36 \%$ & $14.80 \%$ & $\mathbf{8 4 . 8 4 \%}$ \\
$\begin{array}{l}\text { After finishing this course, I feel able to } \\
\text { understand what behavior properties are. }\end{array}$ & $0.00 \%$ & $0.00 \%$ & $0.36 \%$ & $18.41 \%$ & $\mathbf{8 1 . 2 3 \%}$ \\
\hline
\end{tabular}

Table 4. Percentage distribution of answers given by the students in relation to the quality of teaching conditions category.

\begin{tabular}{|c|c|c|c|c|c|}
\hline $\begin{array}{l}\text { Quality of the teaching conditions } \\
\text { Items }\end{array}$ & $\begin{array}{l}\text { Completely } \\
\text { disagree }\end{array}$ & $\begin{array}{l}\text { Partially } \\
\text { disagree }\end{array}$ & $\begin{array}{l}\text { Do not agree } \\
\text { or disagree }\end{array}$ & $\begin{array}{l}\text { Partially } \\
\text { agree }\end{array}$ & $\begin{array}{l}\text { Completely } \\
\text { agree }\end{array}$ \\
\hline $\begin{array}{l}\text { The language used in this course } \\
\text { was easy to understand. }\end{array}$ & $0.00 \%$ & $0.72 \%$ & $1.08 \%$ & $11.55 \%$ & $86.65 \%$ \\
\hline $\begin{array}{l}\text { The images, tables and videos were } \\
\text { important for me to learn the } \\
\text { concepts of this course. }\end{array}$ & $0.00 \%$ & $0.36 \%$ & $1.08 \%$ & $10.47 \%$ & $88.09 \%$ \\
\hline $\begin{array}{l}\text { I felt tired while doing the units of } \\
\text { this course. }\end{array}$ & $31.41 \%$ & $24.19 \%$ & $9.03 \%$ & $26.71 \%$ & $8.66 \%$ \\
\hline $\begin{array}{l}\text { I felt bored while doing the units of } \\
\text { this course. }\end{array}$ & $45.49 \%$ & $23.83 \%$ & $11.55 \%$ & $13.72 \%$ & $5.41 \%$ \\
\hline
\end{tabular}


The concepts contained in the units of this course were clearly $\begin{array}{llll}0.36 \% & 1.45 \% & 0.72 \% & 18.05 \%\end{array}$ $79.42 \%$ presented.

The feedback I received about my answers to the exercises helped my learning.

$$
\begin{array}{lllll}
1.45 \% & 4.69 \% & 5.05 \% & 22.38 \% & \mathbf{6 6 . 4 3 \%}
\end{array}
$$

\begin{tabular}{|c|c|c|c|c|c|}
\hline Items & $\begin{array}{c}\text { Very } \\
\text { difficult }\end{array}$ & Difficult & Regular & Easy & Very easy \\
\hline $\begin{array}{l}\text { Overall, how do you rate the } \\
\text { difficulty of the exercises in this } \\
\text { course? }\end{array}$ & $0.72 \%$ & $9.75 \%$ & $60.29 \%$ & $26.35 \%$ & $2.89 \%$ \\
\hline $\begin{array}{l}\text { Overall, how do you rate the } \\
\text { difficulty of the final test questions } \\
\text { for this course? }\end{array}$ & $4.69 \%$ & $22.02 \%$ & $56.32 \%$ & $16.25 \%$ & $0.72 \%$ \\
\hline
\end{tabular}

Table 5. Percentage distribution of responses presented by the students in relation to the overall user experience category.

\begin{tabular}{lccccc}
\hline \multicolumn{1}{c}{ Overall user experience } & $\begin{array}{c}\text { Completely } \\
\text { disagree }\end{array}$ & $\begin{array}{c}\text { Partially } \\
\text { disagree }\end{array}$ & $\begin{array}{c}\text { Do not agree } \\
\text { or disagree }\end{array}$ & $\begin{array}{c}\text { Partially } \\
\text { agree }\end{array}$ & $\begin{array}{c}\text { Completely } \\
\text { agree }\end{array}$ \\
\hline $\begin{array}{l}\text { I positively evaluate the teaching } \\
\text { method used in this course in relation } \\
\text { to the conventional teaching method. }\end{array}$ & $0.36 \%$ & $0.36 \%$ & $3.25 \%$ & $22.02 \%$ & $\mathbf{7 4 . 0 1 \%}$ \\
$\begin{array}{l}\text { I feel motivated to take other courses } \\
\text { on this platform. }\end{array}$ & $0.36 \%$ & $1.08 \%$ & $1.81 \%$ & $15.52 \%$ & $\mathbf{8 1 . 2 3 \%}$ \\
$\begin{array}{l}\text { I would recommend this course to a } \\
\text { friend or colleague. }\end{array}$ & $0.36 \%$ & $0.72 \%$ & $1.08 \%$ & $12.28 \%$ & $\mathbf{8 5 . 5 6 \%}$ \\
\hline Items & Very bad & Bad & Regular & Good & Very good \\
\hline $\begin{array}{l}\text { Overall, how do you rate your } \\
\text { experience on this course? }\end{array}$ & $0.00 \%$ & $0.00 \%$ & $2.17 \%$ & $22.74 \%$ & $\mathbf{7 5 . 0 9 \%}$ \\
\hline
\end{tabular}

Measuring learning through two distinct procedures is an important educational strategy given its possible effects. If, on one hand, in the self-assessment process, the student can underestimate or overestimate their own abilities (Bibila \& Rabiee, 2014; Charoensap-Kelly et al., 2016) and a more reliable measure of these abilities reduces this bias, on the other hand, self-efficacy beliefs (judgment that the subject makes about their own ability to act in a specific domain (Bandura, 1997)) can motivate the student to participate in other courses. As a result of these beliefs, choice, direction and persistence in learning behaviors will occur (Bzuneck, 2001). 
The quality of the teaching conditions was positively evaluated, especially the language used in the material and the audiovisual resources, as can be seen in Table 4. These data are indicators of the quality of the material used and of the students' preference for simple, easy-to-understand language. These findings strengthen the relevance of Bandeira's (2009) indications. According to the author, one of the functions of the instructional material is to engage the student in teaching-learning activities and the use of graphic resources, such as fonts and illustrations, is important because they enable greater clarity, combining textual and visual information.

As can also be seen in Table 4, the exercises applied during the course and the questions in the final test were evaluated by most students as presenting a regular level of difficulty. The final test was perceived as the most difficult to be answered. If one considers that the aim of the course was to develop learning, expressed in the learning objectives (Kubo \& Botomé, 2001), and that low difficulty was expected in relation to responding to the exercises, then it appears that there is a need to reassess them judiciously. Examples of variables that can be evaluated in relation to the elaborated items are: (a) whether the skills and knowledge that were intended to be developed are measured through the teaching conditions created; (b) whether the alternative response options are clear, similar in size and homogeneous, that is, they deal with the same class of phenomena; (c) whether there is a clearly correct (and complete) answer; and (d) whether the incorrect alternatives are credible, grammatically correct, logically compatible with the question and of the same length as the other answers (Fernández et al., 2013). When teachers examine these items, they prevent a mistaken assessment of the student's learning from being carried out: if the student does not present the desired performance in the item, it will be clear to the teacher whether this fact occurred because the item did not fulfill the described criteria or because the teaching conditions were not relevant and sufficient to develop the expected skills and knowledge.

Considering some of the students' feelings when participating in the course, tiredness stands out (Table 5). Although most reported that they did not feel tired, many of them said they felt this. In part, these data can be attributed to the demand for work produced by the chosen teaching method. According to Taveggia (1976), students of a course in the Personalized System of Instruction (PSI) model, from which the Programming of Teaching was developed, may be forced to pace their studies to avoid accumulation, in an academic semester with deadlines. Even though the course was not part of an academic semester with deadlines, the trial period had a time limit (approximately one month). This limit may have imposed a demand for a fast pace on some participants, making the course more tiring. The mean number of days to complete the course was 9.7, with a standard deviation of 7.62, indicating that the participants tended to complete the course in a shorter period of time than available for testing. It is important to mention that the fatigue of the participants can also be attributed to other variables, such as the conceptual density of the course and the high number of exercises.

Most of the students positively evaluated the teaching method used in relation to the conventional teaching method. This data indicates that the educational principles described in Table 1 are relevant to the development of courses. Finally, the educational principles derived from the behavioral theory constitute the core of the teaching method of the tested course of the Operanda platform. Like the course students, PSI students tend to rate PSI courses as more enjoyable, higher quality and more conducive to learning than conventional classes, in addition 
to having more positive perceptions of the subjects taught through a system based on proficiency (Kulik et al., 1979; Kulik et al., 1990).

\section{Conclusions}

Considering the high rate of completion (44\%), the significant difference between the means of the initial and final tests $(t(276)=34.67, p=.000)$, the very large effect size (Cohen's $d=$ 2.8 ), and the final performance at the level of proficiency (mean=8.8, $s d=0.51$ ), it is possible to conclude that the teaching conditions provided in the course were effective for teaching the learning objectives planned. Through the analysis of the satisfaction questionnaire, it is also possible to identify a very positive perception in relation to the learning that took place, the content learned, the teaching platform and the teaching method used. These results also strengthen the importance of the educational principles proposed by Programming of Teaching as an important contribution of behavioral theories applied to online teaching or, specifically, to the development of MOOCs.

A limitation of the present study was the absence of a measure of the performance of students in a follow-up after the course, in line with the implications of the principle of developing the student's performance capacity to deal with problem-situations in the real world. It is not clear whether what was learned proficiently during the course enabled learners to present such knowledge and skills or whether this learning helped them to deal more effectively with problem-situations in the real world. This measure was not performed in the study, as the course evaluated is the first in a sequence of courses related to direct observation of behavior, with the evaluation of the effects of what was learned in real life being foreseen only for students that complete the full sequence of courses of this training.

Another important question not answered in this study is related to student dropout: at what point did they dropout? Why did they dropout? Even though the course obtained a very high completion rate, the evaluation of factors related to dropout can contribute to the maintenance or improvement of student retention. Another unexamined aspect of great importance is the cost-benefit analysis of the course. The procedure used to produce the teaching material (content, exercises, feedback...) requires more hours of work than planning a face-to-face class or other more traditional online teaching formats. How much the investment in this procedure compensates for the results produced is an important guideline for further studies that use the same educational principles employed in this study.

Acknowledgements: Thank you to all Operanda members who helped proof-read this paper. This work was supported by the National Council for Scientific and Technological Development (CNPq, Brazil); by the Santa Catarina Research and Innovation Foundation (FAPESC) and the Federal University of Santa Catarina (UFSC) (Grant number 2021TR000309).

\section{REFERENCES}


Akera, A. (2017). Bringing Radical Behaviorism to Revolutionary Brazil and Back: Fred Keller's Personalized System of Instruction and Cold War Engineering Education. Journal of the History of the Behavioral Sciences, 1(19). https://doi.org/10.1002/jhbs.21871

Alturkistani, A., Lam, C., Foley, K., Stenfors, T., Blum, E. R., Van Velthoven, M. H., \& Meinert, E. (2020). Massive Open Online Course Evaluation Methods: Systematic Review. Journal of medical Internet research, 22(4). https://doi.org/10.2196/13851

American Educational Research Association (2006). Standards for reporting on empirical social science research in AERA publications. Educational Researcher, 35: 33-40. https://doi.org/10.3102/0013189X035006033

American Psychological Association (2010). Publication manual of the American Psychological Association (6th ed.), Washington, DC.

Anderson, L.W. (2005). Objectives, evaluation, and the improvement of education. Studies in Educational Evaluation, 31, p.102-113. https://doi.org/10.1016/j.stueduc.2005.05.004

Archer. A. B. (2020). Avaliação da efetividade de um programa de ensino para desenvolver comportamentos profissionais. [Evaluating the effectiveness of a teaching program to develop professional behaviors]. Doctoral Thesis. Florianópolis, Brazil: Universidade Federal de Santa Catarina.

Atiaja, L., \& Guerrero-Proenza, R. S. (2016). Moocs: Problems and Challenges in Higher Education. Papers Proceedings of International Conference on Advances in Education, Teaching \& Technology, Toronto, Canada, 1. Pp.82-88.

Bandeira, D. (2009). Materiais Didáticos. IESDE: Curitiba-PR.

Bandura, A. (1997). Self-efficacy: The exercise of control. New York: Freeman.

Baturay, M. H. (2015). An overview of the world of MOOCs. Procedia-Social and Behavioral Sciences, 174, 427-433. https://doi.org/10.1016/j.sbspro.2015.01.685

Baum, W. (2017). Understanding Behaviorism. John Wiley \& Sons. 3rd Edition.

Bibila, S., \& Rabiee, F. (2014). Training the powerful: Issues that emerged during the evaluation of a communication skills training programme for senior cancer care professionals. European Journal of Cancer Care, 23(4), 531-544. https://doi.org/10.1111/ecc.12167

Bloom, B.S. (1956). Taxonomy of educational objectives: Cognitive and affective domains. New York: David McKay.

Bloom, B. S. (1968). Learning for Mastery: Instruction and Curriculum. Regional Education Laboratory for the Carolinas and Virginia, Topical Papers and Reprints, n.1. 
Botomé, S. P., \& Rizzon, L. A. (1997). Medida de desempenho ou avaliação da aprendizagem em um processo de ensino: práticas usuais e possibilidades de renovação. Chronos, 30(1), 7-34.

Botomé, S. P. (1981). Objetivos comportamentais no ensino: a contribuição da Análise Experimental do Comportamento [Behavioral learning objectives: The Experimental Behavior Analysis Contribution]. Doctoral Thesis. Universidade de São Paulo, São Paulo, Brazil.

Botomé, S.P. (2013). The concept of operant behavior as a problem. Brazilian Journal of Behavior Analysis, 9(1), 19-46. http://dx.doi.org/10.18542/rebac.v9i1.2130

Breakwell, G. M., Hammond, S., Fife-Schaw, C., \& Smith, J. A. (Eds.). (2006). Research methods in psychology (3rd ed.). Sage Publications, Inc.

Bzuneck, J. A. (2001). As crenças de auto-eficácia e o seu papel na motivação do aluno. [Self-efficacy beliefs and their role in student motivation]. In: Boruchovitch, E. \& Bzuneck, J. A. A motivação do aluno: contribuições da psicologia contemporânea (2020). Vozes: Petrópolis.

Capacho, J. (2018). Validation of Learning Theories in Their Relationship with Information and Communications Technology. Turkish Online Journal of Distance Education, 19(2). https://doi.org/10.17718/tojde.415831

Carrara, K. (2005). Behaviorismo Radical: Crítica e Metacrítica. [Radical Behaviorism: Criticism and Metacriticism]. São Paulo: Editora Unesp.

Charoensap-Kelly, P., Broussard, L., Lindsly, M., \& Troy, M. (2016). Evaluation of a Soft Skills Training Program. Business and Professional Communication Quarterly, 79(2). https://doi.org/10.1177/2329490615602090

Chiesa, M. (1994). Radical Behaviorism: The Philosophy and the Science.

Cook, B.G., Smith, G.J., \& Tankersley, M. (2012). Evidence-based practices in education. In K. R. Harris, S. Graham, T. Urdan, C. B. McCormick, G. M. Sinatra, \& J. Sweller (Eds.), APA handbooks in psychology®. APA educational psychology handbook, Vol. 1. Theories, constructs, and critical issues (p. 495-527). American Psychological Association. https://doi.org/10.1037/13273-017

Cortegoso, A. L., \& Coser, D. S. (2011). Elaboração de programas de ensino: material auto-instrutivo. [Planning teaching programs: self-instructional material]. São Carlos: EdUFSCar.

Cortegoso, A. L. (2011a). Especificando o repertório de entrada dos aprendizes.[Specifying the learners' stimate repertoire]. In A. L. Cortegoso, \& D. S. Coser, Elaboração de programas de ensino: material autoinstrutivo (pp.148-150). São Carlos: EdUFSCar. 
Cowie, N. \& Sakui, K. (2019). Enhancing student retention rates on open non-formal online language learning courses. Pacific Journal of Technology Enhanced Learning, 1(1), 15-24. https://doi.org/10.24135/pitel.v1i1.17

De Luca, G. G. (2013). Avaliação da eficácia de um programa de contingências para desenvolver comportamentos constituintes da classe geral "avaliar a confiabilidade de informações". [Evaluating the effectiveness of a contingency program to develop behaviors of the general class "evaluating the reliability of information"]. Master Thesis. Florianópolis, Brazil: Universidade Federal de Santa Catarina.

Días, A., Nussbaum, M., Ñopo, H., Maldonado-Carreño, C., \& Corredor, J. (2015). Orchestration: Providing teachers with scaffolding to address curriculum standards and students' pace of learning. Educational Technology \& Society, 18(3), 226-239. Retrieved July 30, 2021, from http://www.jstor.org/stable/jeductechsoci.18.3.226.

Dietz-Uhler, B., Fisher, A., \& Han, A. (2007). Designing Online Courses to Promote Student Retention. Journal of Educational Technology Systems, 36(1), 105-112. https://doi.org/10.2190/et.36.1.g

Diery, A., Vogel, F., Knogler, M., \& Seidel, T. (2020). Evidence-based practice in higher education: Teacher educators' attitudes, challenges, and uses. Frontiers in Education, 5. https://doi.org/10.3389/feduc.2020.00062

Espírito-Santo, H. \& Daniel, F. (2015). Calcular e apresentar tamanhos do efeito em trabalhos científicos (1): As limitações do $\mathrm{p}<0,05$ na análise de diferenças de médias de dois grupos [Calculating and reporting effect sizes on scientific papers (1): $p<0.05$ limitations in the analysis of mean differences of two groups]. Portuguese Journal of Behavioral and Social Research. 1. 3-16. https://doi.org/10.7342/ismt.rpics.2015.1.1.14

Felder, R.M., \& Brent, R. (2016). Teaching and Learning STEM: A practical guide. San Francisco, CA: Jossey-Bass.

Fernández, R. S. Díaz, C. M., \& García, R. (2013). Formación continuada. Cómo redactar preguntas con opciones de respuesta múltiple. Radiología, 55(1), 28-36.

Fox, E. J. (2004). The personalized system of instruction: A flexible and effective approach to mastery learning. In Evidence-based educational methods (pp. 201-221). Academic Press.

Freire, P. (2000). Pedagogy of freedom: Ethics, democracy, and civic courage. Rowman \& Littlefield Publishers.

Gaytan, J. (2015) Comparing Faculty and Student Perceptions Regarding Factors That Affect Student Retention in Online Education, American Journal of Distance Education, 29:1, 56-66. https://doi.org/10.1080/08923647.2015.994365

Gusso, H.L., Archer, A.B., Luiz, F.B., Sahão, F.T., De Luca, G.G, Henklain, M.H.O., Panosso, M.G., Kienen, N., Beltramello, O., \& Gonçalves, V.M. (2020). Ensino superior em 
tempos de pandemia: diretrizes à gestão universitária. [Higher Education in the Times of Pandemic: University Management Guidelines]. Educação \& Sociedade, 41, e238957. https://doi.org/10.1590/es.238957 .

Hattie, J., \& Timperley, H. (2007). The power of feedback. Review of Educational Research, 77(1), 81-112. https://doi.org/10.3102/003465430298487

Hattie, J. (2009). Visible Learning: A synthesis of over 800 meta-analyses relating to achievement. Routledge: London.

Hattie, J. (2012). Visible learning for teachers: Maximizing impact on learning. Routledge.

Hidalgo, F. J. P., Abril, C. A. H., \& Parra, M. E. G. (2020). MOOCs: Origins, Concept and Didactic Applications: A Systematic Review of the Literature (2012-2019). Technology, Knowledge and Learning, 25, 853-879. https://doi.org/10.1007/s10758-019-09433-6

Jordan, K. (2014). Initial trends in enrolment and completion of massive open online courses. International Review of Research in Open and Distance Learning, 15(1), 133-160. https://doi.org/10.19173/irrodl.v15i1.1651

Kaplan, A.M., \& Haenlein, M. (2016). Higher Education and the digital revolution: About MOOCs, SPOCs, social media, and the Cookie Monster. Business Horizons, 59, 441-450. http://dx.doi.org/10.1016/j.bushor.2016.03.008

Kasch, J., Van Rosmalen, P., \& Kalz, M. (2021). Educational scalability in MOOCs: Analysing instructional designs to find best practices. Computer and education, 161. https://doi.org/10.1016/j.compedu.2020.104054

Kawasaki, H. N. (2013). Avaliação da eficiência de um programa de contingências para desenvolvimento de comportamentos da classe "caracterizar comportamentos-objetivo" a profissionais de uma organização não-governamental do campo da educação. [Evaluation of the efficiency of a contingency program for the development of behavior class "characterizing objective behaviors" to professionals of a non-governmental organization in the field of education]. (Master thesis). Universidade Federal de Santa Catarina, Florianópolis.

Khalil, H. \& Ebner, M. (2014). MOOCs Completion Rates and Possible Methods to Improve Retention - A Literature Review. In J. Viteli \& M. Leikomaa (Eds.), Proceedings of EdMedia 2014--World Conference on Educational Media and Technology (pp. 1305-1313). Tampere, Finland: Association for the Advancement of Computing in Education (AACE). Retrieved from https://www.learntechlib.org/primary/p/147656/

Keller, F. S., \& Sherman, J. G. (1974). PSI, the Keller Plan Handbook: Essays on a personalized system of instruction. WA Benjamin Advanced Book Program.

Kienen, N., Kubo, O. M., \& Botomé, S.P. (2013). Ensino programado e programação de condições para o desenvolvimento de comportamentos: alguns aspectos no desenvolvimento de um campo de atuação do psicólogo [Programmed learning and 
programming of conditions to development of behaviors: some aspects on development of an action field of psychology]. Acta Comportamentalia, 21(4), 481-494.

Kirkpatrick, D. L., \& Kirkpatrick, J. D. (2006). Evaluating Training Programs: The Four Levels (3rd ed). Berrett-Koehler Publishers: San Francisco.

Kubo, O. M., \& Botomé, S. P. (2001). Ensino-aprendizagem: Uma interação entre dois processos comportamentais [Teaching and learning: an interaction between two behavioural processes]. Interação em Psicologia, 5, 133-170.

Kulik, J. A., Jaksa, P., \& Kulik, C. L. C. (1978). Research on component features of Keller's Personalized System of Instruction. Journal of Personalized Instruction, 3(1), 2-14.

Kulik, C. L. C., Kulik, J. A., \& Bangert-Drowns, R. L. (1990). Effectiveness of mastery learning programs: A meta-analysis. Review of educational research, 60(2), 265-299.

Kumar, S., Gankotiya, A. K., \& Dutta, K. (2011). A comparative study of moodle with other e-learning systems. In 2011 3rd International Conference on Electronics Computer Technology (Vol. 5, pp. 414-418). IEEE.

Lopes, A.P., Babo, L., Azevedo, J., \& Torres, C. (2018). Rethinking feedback in a connected age. Proceedings of INTED2018 Conference, Spain. https://doi.org/10.21125/inted.2018.1245

Lowyck, J. (2014). Bridging Learning Theories and Technology-Enhanced Environments: A Critical Appraisal of Its History. In: Spector, J.M. et al. (eds.). Handbook of Research on Educational Communications and Technology. Springer. https://doi.org/10.1007/978-1-4614-3185-5_1

Mccourt, M. (2019). Teaching for Mastery. John Catt Educational.

Martin, F., Sun, T., \& Westine, C. D. (2020). A systematic review of research on online teaching and learning from 2009 to 2018. Computers and Education, 159. https://doi.org/10.1016/j.compedu.2020.104009

Martin-Blas, T. \& Serrano-Fernandez, A. (2009). The role of new technologies in the learning process: Moodle as a teaching tool in Physics. Computers \& Education, 52(1), 35-44. https://doi.org/10.1016/j.compedu.2008.06.005

Matos, M. A. (1998). Carolina Bori: A Psicologia Brasileira como Missão. [Carolina Bori: The Brazilian Psychology as a Mission]. Psicologia USP, 9(1), 67-70. https://dx.doi.org/10.1590/S0103-65641998000100009

Means, B., Toyama, Y., Murphy, R., Bakia, M., \& Jones, K. (2009). Evaluation of Evidence-Based Practices in Online Learning: A Meta-Analysis and Review of Online Learning Studies. Washington: Department of Education, Office of Planning, Evaluation, and Policy Development. Center for Technology in Learning. 
Merrill, D. M. (2002). First principles of instruction. Educational Technology Research and Development, 50(3), 43-59.

Merrill, D. M. (2013). First principles of instruction: Identifying and designing effective, efficient and engaging instruction. San Francisco: Wiley.

Moore, J. L., Dickson-Deane, C., \& Galyen, K. (2011). E-Learning, online learning, and distance learning environments: Are they the same? Internet and Higher Education, 14(2), 129-135. https://doi.org/10.1016/j.iheduc.2010.10.001

Muljana, P. S., \& Luo, T. (2019). Factors contributing to student retention in online learning and recommended strategies for improvement: A systematic literature review. Journal of Information Technology Education: Research, 18, 19-57. https://doi.org/10.28945/4182

Nale, N. (1998). Programação de ensino no Brasil: O papel de Carolina Bori. [Programming of Teaching in Brazil: The role of Carolina Bori]. Psicologia USP, 9(1), 275-301.

Popham, W. J., \& Baker, E. L. (1970). Planning an instructional sequence. Prentice-Hall.

Radianti, J., Majchrzak, T.A., Fromm, J., \& Wohlgenannt, I. (2020). A systematic review of immersive virtual reality applications for higher education: Design elements, lessons learned, and research agenda. Computer \& Education, 147. https://doi.org/10.1016/i.compedu.2019.103778

Rice, W. (2015). Moodle e-learning course development. Packt Publishing Ltd.

Rosenthal, J. A. (1996). Qualitative Descriptors of Strength of Association and Effect Size. Journal of Social Service Research, 21(4), 37-59. https://doi.org/10.1300/j079v21n04_02

Saalman, E. (2014). Use of MOOCs to attract young people to Engineering education. In V. VillasBoas, \& O. Giovannini (Eds.), Attracting Young People to Engineering: ALE 2014 (pp. 56-62). Associação Brasileira de Educação em Engenharia (Abenge).

Sancho-Vinuesa, T., Escudero-Viladoms, N., \& Masiá, R. (2013). Continuous activity with immediate feedback: a good strategy to guarantee student engagement with the course. Open Learning, 28:1. https://doi.org/10.1080/02680513.2013.776479

Shaughnessy, J. J., Zechmeister, E. B., \& Zechmeister, J. S. (2012). Research Methods In Psychology. New York: The McGraw-Hill Companies.

Sidman, M. (1989). Coercion and its fallout. Authors Cooperative.

Siemens, G. (2014). Connectivism: A learning theory for the digital age. International Journal of Instructional Technology \& Distance Learning, http://www.itdl.org/Journal/Jan_05/article01.htm

Skinner, B.F. (1968). The technology of teaching. Appleton-Century-Crofts. 
Skinner, B.F. (1974). About Behaviorism. Alfred A. Knopf.

Skinner, B.F. (1986). Programmed Instruction Revisited. The Phi Delta Kappan, 68(2), 103-110. Retrieved from: http://www.jstor.org/stable/20403280

Svenningsen, L., Bottomley, S., \& Pear, J.J. (2018). Personalized Learning and Online Instruction. In: Robert Zheng. Digital Technologies and Instructional Design for Personalized Learning. Hershey, Pennsylvania: IGI Global. https://doi.org/10.4018/978-1-5225-3940-7.ch008

Paton, R. M., Fluck, A. E., \& Scanlan, J. D. (2018). Engagement and retention in VET MOOCs and online courses: A systematic review of literature from 2013 to 2017. Computers and Education, 125(January), 191-201. https://doi.org/10.1016/j.compedu.2018.06.013

Tahiri, J. S., Bennani, S., \& Idrissi, M. K. (2015). Using an analytical formalism to diagnostic and evaluate Massive Open Online Courses. In 2015 10th International Conference on Intelligent Systems: Theories and Applications (SITA) (pp. 1-6). Institute for Electrical and Electronics Engineers (IEEE). https://doi.org/10.1109/SITA.2015.7358389

Taveggia, T. C. (1976). Personalized instruction: A summary of comparative research, 1967-1974. American Journal of Physics, 44(11), 1028-1033.

Times Higher Education (2021, July 20). The World University Rankings. Retrieved from https://www.timeshighereducation.com/world-university-rankings/2020/world-ranking\#!/ page/0/length/25/sort_by/rank/sort order/asc/cols/stats

Tourinho, E. Z. (2003). A produção de conhecimento em psicologia: a análise do comportamento [The knowledge production in psychology: the behavioural analysis]. Psicologia: ciência e profissão, 23(2), 30-41.

Vettorazzi, A.; Frare, E.; Souza, F. C.; Queiroz, F. P.; De Luca, G. G.; Moskorz, L. \& Kubo, O. M. (2005). Avaliação de um programa para ensinar comportamento empático para crianças em contexto clínico [Evaluation of a program to teach emphatic behavior for children in clinic context]. Interação em Psicologia, 9(2). 357 - 371.

Weller, M. (2007). Virtual learning environments: Using, choosing and developing your VLE. Routledge. 